\title{
Síntese de proteína microbiana e concentrações de uréia em vacas alimentadas com dietas à base de palma forrageira e diferentes volumosos ${ }^{1}$
}

\author{
Marcelo de Andrade Ferreira², Renata Rodrigues da Silva ${ }^{3}$, Alenice Ozino Ramos ${ }^{3}$, Antonia \\ Sherlânea Chaves Véras ${ }^{2}$, Airon Aparecido Silva de Melo ${ }^{4}$, Amanda Vasconcelos Guimarães ${ }^{5}$ \\ ${ }_{1}^{1}$ Trabalho realizado pelo acordo UFRPE/IPA, parcialmente financiado pela FACEPE/PROMATA e pelo CNPq. \\ 2 Departamento de Zootecnia/UFRPE. Pesquisador/a do CNPq. \\ 3 Programa de Pós-Graduação em Zootecnia da UFRPE. \\ 4 UAG/UFRPE. \\ ${ }^{5}$ Curso de graduação em Zootecnia-UFRPE. Bolsista de Iniciação Científica - CNPq.
}

RESUMO - Cinco vacas da raça Holandesa foram distribuídas em um quadrado latino $5 \times 5$ com o objetivo de estimar a produção de proteína microbiana utilizando-se a excreção total de derivados de purinas (DP), por meio de coletas spot de urina, e as concentrações de nitrogênio (N)-uréia no plasma, no leite e na urina. As cinco dietas foram formuladas com diversos volumosos (bagaço de cana-de-açúcar; feno de capim-tifton; feno de capim-elefante; silagem de sorgo; e uma mistura de silagem de sorgo + bagaço de cana) associados à palma forrageira. As concentrações de uréia (10,98 mg/dL) e N-uréia (5,11 mg/dL) no leite não foram afetadas pelos volumosos, assim como as concentrações plasmáticas de uréia (28,10 mg/dL) e N-uréia $(13,09 \mathrm{mg} / \mathrm{dL})$. As excreções urinárias de uréia, N-uréia, alantoína e derivados de purina, purinas absorvidas, a síntese de N-microbiano e as concentrações de alantoína no leite não foram alteradas. Os volumosos utilizados podem ser associados a palma forrageira na alimentação de vacas Holandesas, pois não alteram a produção de proteína microbiana.

Palavras-chave: amostra spot, creatinina, derivados de purina, semi-árido

\section{Microbial protein synthesis and urea nitrogen concentrations in lactating dairy cows fed spineless cactus and different forages based diets}

\begin{abstract}
Five Holstein cows were allotted to a $5 \times 5$ Latin square design with the objective of evaluating the microbial protein production, using the total excretion of purine derivatives (PD), obtained from spot urine collection, plasma and milk urea and nitrogen $(\mathrm{N})$-urea. The five treatments contained different forage sources: sugar cane bagasse (CB), tifton hay (TH), elephant grass hay (EH), sorghum silage (SS) and a mixture of sugar cane bagasse + sorghum silage (CBSS) The milk urea $(10.98 \mathrm{mg} / \mathrm{dL})$ and $\mathrm{N}$-urea $(5.11 \mathrm{mg} / \mathrm{dL})$ concentrations were not influenced by the forage sources, such as plasma urea $(28.10 \mathrm{mg} / \mathrm{dL})$ and $\mathrm{N}$-urea $(13.09 \mathrm{mg} / \mathrm{dL})$ concentrations. The urinary urea, N-urea, allantoin and PD excretions, the absorbed purine, N-microbial synthesis and milk allantoin concentration remained unchanged. The different forage sources in association with forage cactus did not change the microbial protein production.
\end{abstract}

Key Words: creatinine, purine derivatives, semi-arid, spot sample

\section{Introdução}

A palma forrageira tem sido utilizada como base na alimentação do rebanho em importantes bacias leiteiras do Nordeste, por ser uma cultura adaptada às condições edafoclimáticas locais e excelente fonte de energia, rica em carboidratos não-fibrosos. Entretanto, possui baixos teores de fibra em detergente neutro, o que exige sua associação a fontes de fibra de alta efetividade, como silagens, fenos, capins e subprodutos disponíveis na região.

As exigências protéicas dos ruminantes são atendidas mediante a absorção intestinal de aminoácidos provenientes principalmente da proteína microbiana sintetizada no rúmen e da proteína de origem alimentar não-degradada no rúmen (Valadares Filho, 1995). O tipo de volumoso utilizado na dieta influencia a síntese microbiana, pois promove alterações no pH e na taxa de passagem, principais modificadores químicos e fisiológicos da fermentação no rúmen (Hoover \& Stokes, 1991).

A eficiência de produção microbiana e o fluxo microbiano são fatores determinantes da fração protéica que alcança o intestino delgado. A proteína sintetizada no rúmen possui excelente perfil de aminoácidos e composição pouco variável (NRC, 2001). Assim, o estudo dos mecanismos 
relacionados à síntese protéica microbiana, visando sua melhora, são de grande relevância, pois estão diretamente associados ao desempenho animal.

O balanceamento entre o suprimento de nitrogênio (N) e energia para os microrganismos ruminais tem sido proposto como mecanismo para melhorar a captura do nitrogênio degradável no rúmen e aumentar o crescimento microbiano. Em períodos de excesso de nitrogênio, a amônia é absorvida no epitélio ruminal e, uma vez na circulação portal, é convertida em uréia no fígado (Van Soest, 1994).

Se a produção de amônia no rúmen é grande, o aumento da atividade de reciclagem da uréia no fígado e rim é necessário para proteger o animal de seu efeito tóxico (Nocek \& Russell, 1988). Dessa forma, o teor de N-uréico no soro tem sido utilizado com a finalidade de fornecer informações sobre o metabolismo protéico nos ruminantes, incluindo a resposta metabólica desses animais a determinadas dietas. A excreção urinária de uréia reflete a concentração sérica de uréia.

Objetivou-se avaliar o efeito da associação de palma a diferentes volumosos sobre a estimativa da produção, a eficiência de síntese de proteína microbiana e as concentrações de uréia na urina uréia e $\mathrm{N}$-uréico no plasma e no leite de vacas da raça Holandesa.

\section{Material e Métodos}

O experimento foi conduzido na Estação Experimental de São Bento do Una, pertencente ao Instituto Agronômico de Pernambuco (IPA), no período de agosto a novembro de 2003, localizado na mesorregião do Agreste Setentrional e microrregião do Vale do Ipojuca, a $8^{\circ} 31^{\prime} 16$ "de latitude sul e $36^{\circ} 33^{\prime} 0$ "de longitude oeste e $650 \mathrm{~m}$ de altitude. A precipitação pluviométrica média da região é de 601,6 mm por ano e se concentra nos meses de março a julho, quando corresponde a aproximadamente $60 \%$ do volume total anual. As temperaturas mais elevadas são observadas nos meses de novembro a janeiro e são superiores a $30^{\circ} \mathrm{C}$. A temperatura média mensal varia de $21,0^{\circ}$ a $24,6^{\circ} \mathrm{C}$, com média anual de $23,0^{\circ} \mathrm{C}$. A umidade relativa do ar em média de $66 \%$ (FIDEPE, 1982).

Foram utilizadas cinco vacas da raça Holandesa, variedade preto e branco, com peso corporal (PC) médio de 560 kg, produção inicial de leite de $20 \mathrm{~kg} /$ dia e período de lactação em torno de 100 dias e nenhum animal havia sido inseminado quando iniciou o trabalho.

Os animais foram distribuídos em quadrado latino $5 \times 5$, composto de cinco animais, cinco fontes de volumoso e cinco períodos experimentais. Cada período teve duração de 14 dias, sete para adaptação às dietas e sete para coleta de dados e amostras, totalizando 70 dias. Os tratamentos experimentais consistiram de ração completa contendo palma forrageira cv. Gigante (Opuntia fícus indica, Mill) associada a bagaço de cana; feno de capim-tifton, (Cynodon spp.); feno de capim-elefante (Pennisetum purpureun, Schum); silagem de sorgo (Sorghum bicolor (L.) Moench); ou mistura de silagem de sorgo e bagaço de cana (Tabela 1).

Os animais, após o controle de ecto e endoparasitos, passaram por um período de 14 dias de adaptação ao manejo experimental e às instalações. As pesagens foram realizadas no início e final de cada período experimental e os animais foram mantidos em baias individuais com piso de terra, separadas por cerca de arame farpado com área coberta de $6 \mathrm{~m}^{2}$, dotadas de cochos e bebedores para controle do consumo de alimentos e água. A alimentação foi oferecida duas vezes ao dia (6h30 e 15h30) na forma de mistura completa, permitindo sobras de 5 a $10 \%$ do total de matéria seca fornecida como forma de manter os níveis dos ingredientes das dietas.

Tabela 1 - Composição dos ingredientes das dietas experimentais

\begin{tabular}{|c|c|c|c|c|c|c|c|c|}
\hline Item & Palma & $\begin{array}{l}\text { Bagaço de } \\
\text { cana }\end{array}$ & $\begin{array}{c}\text { Feno de } \\
\text { capim-tifton }\end{array}$ & $\begin{array}{c}\text { Feno de } \\
\text { capim-elefante }\end{array}$ & $\begin{array}{l}\text { Silagem de } \\
\text { sorgo }\end{array}$ & $\begin{array}{l}\text { Farelo de } \\
\text { soja }\end{array}$ & $\begin{array}{l}\text { Milho } \\
\text { moído }\end{array}$ & $\begin{array}{l}\text { Farelo de } \\
\text { trigo }\end{array}$ \\
\hline Matéria seca (\%) & 13,37 & 84,19 & 82,00 & 81,99 & 26,25 & 88,99 & 88,43 & 88,50 \\
\hline Proteína bruta ${ }^{1}$ & 3,00 & 1,24 & 8,54 & 6,11 & 5,82 & 49,94 & 9,24 & 16,59 \\
\hline Fibra em detergente neutro ${ }^{1}$ & 31,62 & 79,04 & 64,18 & 64,81 & 67,08 & 12,13 & 15,58 & 36,83 \\
\hline Extrato etéreo ${ }^{1}$ & 1,55 & 0,18 & 1,49 & 1,25 & 2,01 & 2,08 & 4,02 & 3,31 \\
\hline Matéria mineral ${ }^{1}$ & 9,31 & 3,45 & 8,57 & 8,35 & 7,14 & 8,43 & 1,88 & 8,39 \\
\hline Carboidratos não-fibrosos ${ }^{1}$ & 55,49 & 17,36 & 21,81 & 21,87 & 34,98 & 30,52 & 64,31 & 39,22 \\
\hline Lignina $^{1}$ & 6,87 & 18,69 & 9,65 & 11,67 & 8,88 & 2,24 & 3,68 & 5,75 \\
\hline Nitrogênio digestível total ${ }^{1,2}$ & 69,34 & 44,85 & 56,71 & 53,08 & 58,09 & 83,96 & 90,01 & 73,56 \\
\hline
\end{tabular}

\footnotetext{
$1 \%$ na MS.

${ }^{2}$ Estimado pela equação do NRC (2001).
} 
Tabela 2 - Composição das dietas experimentais, com base na matéria seca

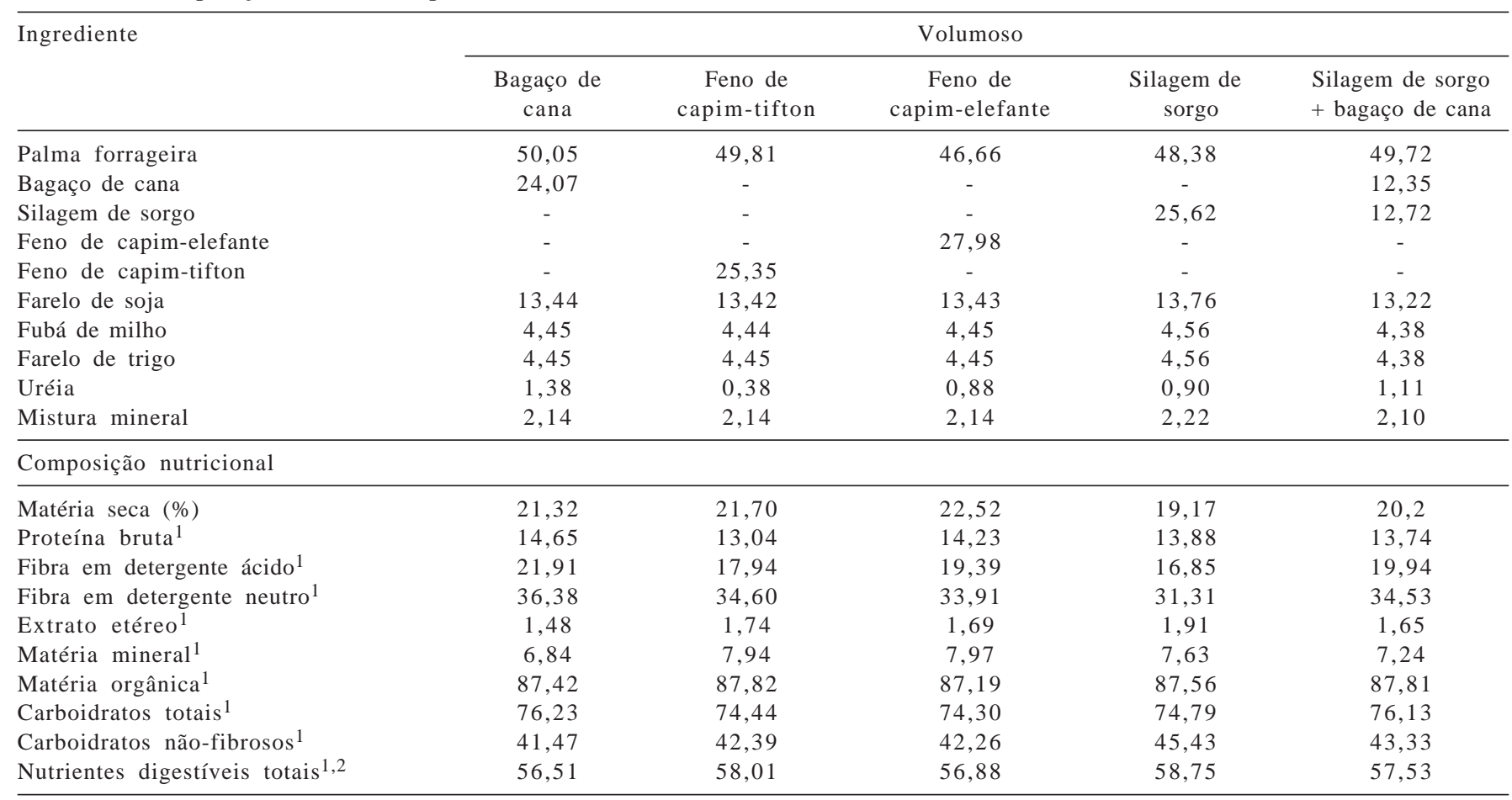

$1 \%$ da matéria seca.

${ }^{2}$ Valor estimado por meio de ensaio de digestibilidade.

Diariamente, os animais foram transferidos nas horas mais quentes do dia para um local sombreado, onde permaneceram das 10 às $15 \mathrm{~h}$, quando eram levados para o estábulo de ordenha e retornavam às baias experimentais. Esse manejo foi adotado no intuito de diminuir o desconforto térmico dos animais.

As dietas foram formuladas de acordo com as recomendações do NRC (2001), para atender às exigências de vacas em lactação com produção de leite em torno de $20 \mathrm{~kg} /$ dia com 3,5\% de gordura, de acordo com o peso vivo dos animais.

O bagaço de cana-de-açúcar utilizado foi adquirido de usinas e armazenado em local seco e arejado. A silagem e o feno de capim-elefante foram confeccionados na própria estação experimental onde foi conduzido o experimento. A silagem foi produzida com a variedade de sorgo SF-25 e armazenada em silo tipo trincheira e o feno de capim-tifton utilizado foi adquirido em casa comercial. A palma foi picada em máquina forrageira no momento do fornecimento e misturada à fonte volumosa e ao alimento concentrado no cocho.

As análises para determinação dos teores de matéria seca (MS), matéria mineral (MM), proteína bruta (PB), extrato etéreo (EE), fibra em detergente neutro (FDN), fibra em detergente ácido (FDA) e lignina (LIG) foram realizadas conforme descrito por Silva \& Queiroz (2002). Os carboidratos totais (CT) foram calculados de acordo com Sniffen et al. (1992): CT = 100 - (\%PB + \%EE + \%cinzas). Em razão da presença de uréia nas dietas, os teores de carboidratos não-fibrosos (CNF) foram obtidos conforme proposto por Hall (2001): CNF $=100$ - [(\%PB - \%PB derivada da uréia + \%uréia) +\%FDN $\mathrm{Fp}_{\mathrm{p}}+\% \mathrm{EE}+\%$ cinzas $]$.

Durante o período de coleta, foram realizadas coletas spot de urina, obtidas no $8^{0}$ dia de cada período experimental, aproximadamente 4 horas após a alimentação matinal, durante micção espontânea. Uma alíquota de $10 \mathrm{~mL}$ foi diluída em $40 \mathrm{~mL}$ de ácido sulfúrico $0,036 \mathrm{~N}$. Após a diluição, foi aferido o pH, que foi ajustado, caso necessário, para valores inferiores a 3, com pequenas gotas de ácido sulfúrico concentrado, a fim de evitar destruição bacteriana dos derivados de purina e precipitação do ácido úrico. As amostras foram armazenadas a $-20^{\circ} \mathrm{C}$ para posterior análise de creatinina, uréia, alantoína e ácido úrico. $\mathrm{Na}$ mesma ocasião, foram coletadas amostras de sangue de cada animal, por punção da veia jugular, utilizando-se heparina como anticoagulante. As amostras foram imediatamente centrifugadas a $5.000 \mathrm{rpm}$ durante 15 minutos. $\mathrm{O}$ plasma resultante foi armazenado a $-20^{\circ} \mathrm{C}$ para posterior determinação dos teores de uréia.

Amostras de leite das duas ordenhas de cada animal foram coletadas no $6 \underline{0}$ e $7 \underline{0}$ dias de coleta. Uma quantidade de $10 \mathrm{~mL}$ de leite foi misturada com $5 \mathrm{~mL}$ de ácido 
tricloroacético a 25\%, filtrada em papel-filtro e armazenada a $-20^{\circ} \mathrm{C}$ para análise de uréia e alantoína.

As análises de uréia no plasma, na urina e no leite desproteinado, de creatinina na urina e de ácido úrico na urina foram realizadas utilizando-se kits comerciais (Labtest), segundo orientações dos fabricantes. As análises foram realizadas no Laboratório de Nutrição Animal do Departamento de Zootecnia da UFRPE. As análises de alantoína na urina e no leite desproteinado foram feitas pelo método colorimétrico, descrito por Chen \& Gomes (1992).

O volume urinário médio diário foi estimado para cada animal, multiplicando-se o respectivo peso corporal pela excreção diária de creatinina (mg/ kg de PC) e dividindo-se esse produto pela concentração de creatinina (mg/L) na urina spot, utilizando-se o valor $24,4 \mathrm{mg} / \mathrm{kg}$ de PC de creatinina, encontrado por Pereira (2003), em vacas nos terços inicial e médio de lactação.

A excreção total de derivados de purinas (DP) foi calculada pela soma das quantidades de alantoína excretada na urina e no leite, e pela excreção de ácido úrico na urina, expressa em mmol/dia.

As purinas absorvidas (PA) (X, mmol/dia) foram calculadas a partir da excreção de $\mathrm{DP}(\mathrm{Y}, \mathrm{mmol} / \mathrm{dia})$ por intermédio da equação $\mathrm{X}=\left[\mathrm{Y}-\left(0,385 \times \mathrm{PV}^{0,75}\right)\right] / 0,85$, em que 0,85 é a recuperação de purinas absorvidas como DP e 0,385 x $\mathrm{PC}^{0,75}$, a contribuição endógena para a excreção de purinas (Verbic et al., 1990).

A síntese ruminal de nitrogênio (Y, gN/dia) foi calculada em relação às purinas absorvidas ( $\mathrm{X}, \mathrm{mmol} / \mathrm{dia})$ utilizando-se uma modificação de equação descrita por Chen \& Gomes (1992), substituindo-se a relação N-purina:N-total nas bactérias de 0,116 por 0,134, conforme descrito por Valadares et al. (1999): $Y=70 \mathrm{X} /(0,83 \times 0,134 \times 1000)$, em que 70 é o nitrogênio de purinas (mgN/mol); 0,134, a relação $\mathrm{N}$-purina: $\mathrm{N}$ total das bactérias e 0,83 , a digestibilidade das purinas microbianas. A eficiência de síntese microbiana foi calculada da seguinte forma: $E S P B m i c=[(0,629 \times \mathrm{PA}) \mathrm{x}$ 6,25)]/CNDT.

Os resultados foram submetidos à análise de variância e as médias comparadas pelo teste Tukey a 5\% de probabilidade, utilizando-se o Sistema de Análise Estatística e Genéticas - SAEG 8.0(UFV, 1998)

\section{Resultados e Discussão}

A produção de leite $(16,20 ; 17,63 ; 17,55 ; 18,36$ e 18,13 kg/dia) e o consumo de matéria seca $(17,77 ; 17,52 ; 17,97$; 18,77 e 18,83 kg/dia para bagaço de cana-de-açúcar, feno de capim-tifton, feno de capim-elefante, silagem de sorgo e silagem de sorgo + bagaço de cana, respectivamente) não diferiram significativamente entre as fontes volumosas.

O volume urinário estimado pelo indicador metabólico creatinina não foi influenciado $(\mathrm{P}>0,05)$ pelos volumosos (Tabela 4), provavelmente porque não houve diferença significativa na produção de leite e no consumo de matéria seca. Segundo o NRC (2001), as perdas de água pelo animal ocorrem principalmente pela produção de leite e pelas perdas fecais e urinárias. As perdas pelo leite e pelas fezes são similares, próximas a 35\% da ingestão total de água, respectivamente; enquanto a perda pela urina é próxima à metade das perdas fecais e varia de 15 a $21 \%$ em vacas em lactação.

O requerimento de água pelos animais, estimado por meio da equação de Murphy et al. (1993), citados pelo NRC (2001), seria em média de $84,00 \mathrm{~kg} / \mathrm{dia}$, o que leva a uma estimativa de excreção diária de urina de 14,3 e 17,6 L/dia, para os valores de 17 e $21 \%$ das perdas totais de água preconizadas. Portanto, estes valores creditam o indicador creatinina para estimar o volume urinário com segurança.

A excreção média de ácido úrico foi de $6,00 \mathrm{mmol} / \mathrm{dia}$ e não diferiu $(\mathrm{P}>0,05)$ entre as fontes de volumoso avaliadas. Esse valor foi próximo ao encontrado por Magalhães et al. (2005), de 8,64 mmol/dia, em animais em crescimento, e inferior àquele observado por Silva et al. (2001), de 23,81 mmol/dia, em vacas em lactação.

As excreções urinárias de alantoína não foram alteradas $(\mathrm{P}>0,05)$ pelas fontes de volumoso e apresentaram média de 293,25 mmol/dia. Esses resultados representam aproximadamente 93\% do total excretado de derivados de purina, pouco acima dos valores encontrados por Oliveira et al. (2001) e Vagnoni et al. (1997), de 85,4 e 86,6\%, respectivamente.

A excreção de alantoína na urina reflete a excreção total de derivados de purinas em aproximadamente 85\% (Verbic et al., 1990). Desta forma, Puchala \& Kulasek (1992) sugeriram não realizar todas as análises dos derivados de purinas, mas apenas as de alantoína. A secreção de alantoína no leite, que foi em média 13,71 mmol/dia, também não foi influenciada pelas fontes de volumoso, provavelmente porque não houve variação na produção de leite dos animais utilizados neste experimento.

As excreções de derivados de purina totais e purinas absorvidas não foram influenciadas $(\mathrm{P}>0,05)$ pelas fontes de volumoso avaliadas e apresentaram médias de 312,37 e 315,23 mmol/dia, respectivamente. Silva et al. (2001) trabalhando com vacas mestiças em lactação, também não encontraram diferença significativa para as excreções de derivados de purinas e purinas absorvidas, que apresentaram média de 311,3 e 317,04 mmol/dia, respectivamente. 
Tabela 3 - Volume urinário e excreções urinárias diárias de creatinina, alantoína, alantoína no leite e alantoína total, purinas totais e purinas absorvidas e sínteses de nitrogênio microbiano e proteína bruta microbiana

\begin{tabular}{lccccc}
\hline Item & \multicolumn{3}{c}{ Volumoso } \\
\cline { 2 - 5 } & $\begin{array}{c}\text { Bagaço de } \\
\text { cana }\end{array}$ & $\begin{array}{c}\text { Feno de } \\
\text { capim-tifton }\end{array}$ & $\begin{array}{c}\text { Feno de } \\
\text { capim-elefante }\end{array}$ & $\begin{array}{c}\text { Silagem de } \\
\text { sorgo }\end{array}$ & $\begin{array}{c}\text { Silagem de sorgo } \\
\text { + bagaço de cana }\end{array}$ \\
\hline Volume urinário estimado (L) & 17,04 & 20,95 & 22,12 & 18,38 & 17,89 \\
\hline Excreção urinária & & & & 14,59 \\
Ácido úrico (mmol/dia) & 6,37 & 7,17 & 5,89 & 5,15 & 5,43 \\
Alantoína (mmol/dia) & 278,38 & 318,93 & 274,27 & 298,12 & 296,54 \\
Alantoína no leite (mmol/dia) & 13,04 & 13,97 & 13,42 & 14,24 & 13,88 \\
Alantoína total (mmol/dia) & 291,42 & 332,90 & 287,70 & 312,36 & 310,42 \\
Derivados de purina totais (mmol/dia) & 297,51 & 337,43 & 292,89 & 317,86 & 316,14 \\
Purinas absorvidas (mmol/dia) & 298,40 & 345,03 & 292,32 & 320,46 & 319,94 \\
Sínteses de nitrogênio microbiano (gN/dia) & 187,69 & 217,03 & 183,87 & 201,57 & 23,52 \\
Síntese de proteína bruta microbiana (g/dia) & $1.173,09$ & $1.356,42$ & $1.149,17$ & $1.259,81$ & 27,24 \\
\hline
\end{tabular}

Médias seguidas de letras diferentes na mesma linha diferem $(\mathrm{P}<0,05)$ entre si pelo teste Tukey.

As sínteses de nitrogênio e proteína bruta microbiana não foram alteradas pela fonte volumosa $(\mathrm{P}>0,05)$ e apresentaram médias de 198,28 gN/dia e 1.239,25 gPB/dia, respectivamente. Silva et al. (2001), em pesquisa com vacas mestiças em lactação, encontraram valores semelhantes $(199,44$ gN/ dia e 1246,5 gPB/dia). Ressalta-se que os teores de PB e CNF das dietas experimentais foram próximos e que grande proporção desses componentes foi fornecida pelo concentrado e pela palma forrageira. Esses dois ingredientes praticamente se mantiveram na mesma proporção, o que pode ter contribuído para o comportamento verificado.

A excreção urinária de uréia (UU) apresentou média de $300,81 \mathrm{mg} / \mathrm{kgPC}$ e não diferiu $(\mathrm{P}>0,05)$ entre os volumosos (Tabela 4). Oliveira et al. (2001) encontraram excreções de uréia variando de 217,05 a 358,80 mg/kgPC, enquanto Silva et al. (2001) relataram média de 395,51 mg/kgPC, o que mostra que os resultados encontrados neste estudo ficaram entre os valores encontrados na literatura consultada.

As concentrações médias de uréia e $\mathrm{N}$-uréia plasmáticas foram de 28,10 e 13,09 mg/dL, respectivamente, e não foram alteradas pelas fontes de volumoso avaliadas. Estes valores estão na faixa de variação encontrada na literatura, como os valores obtidos por Cruz (2002), de 31,37 e 14,62 mg/dL, Oliveira et al. (2001), de 35,52 a 49,52 e 23,08 a 16,43 mg/dL e Valadares et al. (1999), de 22,8 e 17,3 mg/dL, respectivamente. As concentrações de uréia e nitrogênio uréico no plasma dependem das quantidades de proteína e energia da dieta. A excreção urinária de uréia seguiu o mesmo comportamento de N-uréia no plasma, o que confirma a afirmação de Harmeyer \& Martens (1980) de que a quantidade de uréia excretada na urina é influenciada principalmente pela sua concentração no plasma. A grande proporção de carboidratos não-fibrosos nas dietas, decorrente da grande participação de palma forrageira em todos os volumosos, parece ter contribuído para a melhor utilização da amônia no rúmen, mesmo com o fornecimento de bagaço de cana, quando a uréia teve participação maior (1,38\%). Segundo Butler et al. (1996) e Oliveira et al. (2001), concentrações de nitrogênio uréico no plasma superiores a 19 mg/dL representam o limite para a perda de nitrogênio dietético em vacas em lactação.

As concentrações de uréia e N-uréia no leite não diferiram significativamente entre os volumosos (médias de 10,98 e $5,11 \mathrm{mg} / \mathrm{dL}$, respectivamente). Este fato provavelmente ocorreu em razão da ausência de significância nas variáveis uréia e N-uréia no plasma, pois, segundo Kauffman \& St-pierre (2001), citados por Cruz (2002), o aumento na amônia no rúmen eleva a concentração sanguínea de uréia e conseqüentemente sua difusão para o leite. A concentração de uréia no leite pode ser um potente indicador do metabolismo protéico em vacas (Roseler et al., 1993; Jonker et al., 1998).

A eficiência de síntese de proteína bruta microbiana média entre as fontes de volumoso, de 111,32 gPBmic/kg NDT, foi próxima à preconizada pelo NRC (2001), de 130 gPBmic/kg NDT. A síntese de proteína microbiana depende, em grande parte, da disponibilidade de carboidratos e de nitrogênio no rúmen (Clark et al., 1992; NRC, 2001), portanto, o crescimento microbiano aumenta com a sincronização entre a disponibilidade da energia fermentável e o nitrogênio degradável no rúmen (Russell et al., 1992; NRC, 1996). Considerando esses resultados, pode-se inferir que não houve limitação ao crescimento dos microrganismos neste estudo.

Os resultados desse estudo ressaltam a importância da associação da palma forrageira, alimento muito utilizado no arraçoamento de rebanhos leiteiros nas regiões semi-áridas do Nordeste brasileiro. A escolha do volumoso, no entanto, 
Tabela 4 - Excreções de uréia na urina e concentrações de uréia e n-uréia no plasma e de uréia e n-uréia (NUL) no leite e eficiência de síntese de proteína bruta microbiana obtidas com os volumosos avaliados

\begin{tabular}{|c|c|c|c|c|c|c|}
\hline & \multicolumn{5}{|c|}{ Volumoso } & \multirow[t]{2}{*}{ CV (\%) } \\
\hline & $\begin{array}{l}\text { Bagaço de } \\
\text { cana }\end{array}$ & $\begin{array}{c}\text { Feno de } \\
\text { capim-tifton }\end{array}$ & $\begin{array}{c}\text { Feno de } \\
\text { capim-elefante }\end{array}$ & $\begin{array}{l}\text { Silagem de } \\
\text { sorgo }\end{array}$ & $\begin{array}{l}\text { Silagem de sorgo } \\
+ \text { bagaço de cana }\end{array}$ & \\
\hline Uréia no plasma (mg/dL) & 29,00 & 26,07 & 28,74 & 28,33 & 28,39 & 27,89 \\
\hline N-uréia no plasma (mg/dL) & 13,51 & 12,15 & 13,39 & 13,20 & 13,23 & 27,89 \\
\hline Uréia no leite (mg/dL) & 11,45 & 10,03 & 11,75 & 10,94 & 10,74 & 26,49 \\
\hline
\end{tabular}

proteína bruta microbiana

(gPBmic/kg NDT)

Médias seguidas de letras diferentes na mesma linha diferem $(\mathrm{P}<0,05)$ entre si pelo teste Tukey.

depende da disponibilidade e do custo de produção ou aquisição.

\section{Conclusões}

A síntese de proteína microbiana e as concentrações de uréia não são influenciados pelas fontes de volumoso avaliadas, o que sugere a viabilidade de utilização de qualquer um deles para animais com produção de $18 \mathrm{~kg}$ de leite/dia alimentados com palma forrageira e concentrado, respectivamente, nas proporções de 50 e 25\% da matéria seca da dieta.

\section{Literatura Citada}

BUTLER, W.R.; CALAMAN, J.J.; BEAM, S.W. Plasma and milk urea nitrogen in relation to pregnancy rate in lactating dairy cows. Journal of Animal Science, v.74, n.4, p.858-865, 1996.

CHEN, X.B.; GOMES, M.J. Estimation of microbial protein supply to sheep an cattle based on urinary excretion of purine derivatives: an overview of technical details. Aberdeen: Rowett Research Institute/International Feed Research Unit, 1992, 21p. (Ocasional Publiation).

CLARK, J.H.; KLUSMEYER, T.H.; CAMERON, M.R. Microbial protein synthesis and flows of nitrogen fractions to the duodenum of dairy cows. Journal of Dairy Science, v.75, n.8, p.2304-2323, 1992.

CRUZ, M.C.S. Estimativas de perdas endógenas e balanço de nitrogênio em vacas lactantes alimentadas com níveis crescentes de uréia e mandioca. 2002. 73f. Dissertação (Mestrado em Zootecnia) - Universidade Federal Rural de Pernambuco, Recife, 2002.

FUNDAÇÃO DE INFORMAÇÕES PARA O DESENVOLVIMENTO DE PERNAMBUCO/FIDEPE, 1982. São Bento do Una. Recife, 1982. 80p. (Monografias Municipais).

HALL, M.B. Calculation of non-structural carbohydrate content of feeds that contain non-protein nitrogen. Gainesville: University of Florida, 2001. p.A-25. (Bulletin 339).

HARMEYER, J.; MARTENS, H. Aspects of urea metabolism with reference to the goat. Journal of Dairy Science, v.63, n.10, p.1707-1728, 1980.

HOOVER, W.H.; STOKES, S.R. Balancing carbohydrates and proteins for optimum rumen microbial yield. Journal of Dairy Science, v.74, n.8, p.3630-3644, 1991.
JONKER, J.S.; KOHN, R.A.; ERDMAN, R.A. Using milk urea nitrogen to predict nitrogen excretion and utilization efficiency in lactating dairy cows. Journal of Dairy Science, v.81, n.10, p.2681-2692, 1998.

MAGALHÃES, K.A.; VALADARES FILHO, S.C.; VALADARES, R.F.D. et al. Produção de proteína microbiana, concentração plasmática de uréia e excreções de uréia em novilhos alimentados com diferentes níveis de uréia ou casca de algodão. Revista Brasileira de Zootecnia, v.34, n.4, p.1400-1407, 2005.

NATIONAL RESEARCH COUNCIL - NRC. Nutrient requirements of beef cattle. 7.ed. Washington, D.C.: National Academy Press, 1996. 242p.

NATIONAL RESEARCH COUNCIL - NRC. Nutrient requirements of the dairy cattle. 7.ed. Washington, D.C.: National Academy Press, 2001. 363p.

NOCEK, J.E.; RUSSELL, J.B. Protein and energy as an integrated system. Relation of ruminal protein and carbohydrates availability to microbial synthesis and milk production. Journal of Dairy Science, v.71, n.8, p.2070-2107, 1988.

OLIVEIRA, A.S.; VALADARES, R.F.D.; VALADARES FILHO, S.C et al. Produção de proteína microbiana e estimativas das excreções de derivados de purinas e de uréia em vacas lactantes alimentadas com rações isoprotéicas contendo diferentes níveis de compostos nitrogenados não-protéicos. Revista Brasileira de Zootecnia, v.30, n.5, p.1621-1629, 2001.

PEREIRA, M.L.A. Proteína na dieta de vacas nos terços inicial e médio de lactação. 2003. 105f. Tese (Doutorado em Zootecnia) - Universidade Federal de Viçosa, Viçosa, MG, 2003.

PUCHALA, R.; KULASEK, G.W. Estimation of microbial protein flow from the rumen of sheep using microbial nucleic acid and excretion of purine derivatives. Canadian Journal of Animal Science, v.72, n.6, p.821-830, 1992.

ROSELER, D.K.; FERGUSON, J.D.; SNIFFEN, C.J. Dietary protein degradability effects on plasma and milk urea nitrogen and milk nonprotein nitrogen in holstein cows. Journal of Dairy Science, v.76, n.2, p.525-534, 1993.

RUSSELL, J.B.; O'CONNOR, J.D.; FOX, D.G. et al. A net carbohydrate and protein system for evaluating cattle diets: I. Ruminal fermentation. Journal of Animal Science, v.70, n.11, p.3551-3561, 1992

SILVA, D.J.; QUEIROZ, A.C. Análise de alimentos (métodos químicos e biológicos). 3.ed. Viçosa, MG: Editora UFV, 2002. 235p.

SILVA, R.M.N.; VALADARES, R.F.D.; VALADARES FILHO, S.C. et al. Uréia para vacas em lactação. 2. Estimativas do volume urinário, da produção microbiana e da excreção de uréia. Revista Brasileira de Zootecnia, v.30, n.6, p.1948-1957, 2001.

SNIFFEN, C.J.; O'CONNOR, J.D.; Van SOEST, P.J. et al. A net carbohydrate and protein system for evaluating cattle diets: II. Carbohydrate and protein availability. Journal of Animal Science, v.70, n.11, p.3562-3577, 1992. 
UNIVERSIDADE FEDERAL DE VIÇOSA - UFV. SAEG - Sistema de análise estatística e genética, versão 8.0. Viçosa, MG: 1998, 150p. (Manual do usuário).

VAGNONI, D.B.; BRODERICK, G.A.; CLAYTON, M.K. et al. Excretion of purine derivatives by Holstein cows abomasally infused with incremental amounts of purines. Journal of Dairy Science, v.80, n.8, p.1695-1702. 1997.

VALADARES, R.F.D.; BRODERICK, G.A.; VALADARES FILHO, S.C. et al. Effect of replacing alfalfa silage with high moisture corn on ruminal protein synthesis estimated from excretion of total purine derivatives. Journal of Dairy Science, v.82, n.12, p.2686-2696, 1999.
VALADARES FILHO, S.C. Eficiência da síntese de proteína microbiana, degradação ruminal e digestibilidade intestinal da proteína bruta, em bovinos. In: SIMPÓSIO INTERNACIONAL SOBRE EXIGÊNCIAS NUTRICIONAIS DE RUMINANTES, 1995, Viçosa, MG. Anais... Viçosa, MG: Universidade Federal de Viçosa, 1995. p.355-388.

Van SOEST, P.J. Nutritional ecology of the ruminant. 2.ed. London: Constock Publishing Associates, 1994. 476p.

VERBIC, J.; CHEN, X.B.; MACLEOD, N.A. et al. Excretion of purine derivatives by ruminants. Effect of microbial nucleic acid infusion on purine derivatives excretion by steers. Journal of Agricultural Science, v.114, n.3, p.243-248, 1990. 